\title{
CRIANÇA MIGRANTE: AS NARRATIVAS DE MEMÓRIA DE TATIANA BELINKY E ELISA LISPECTOR
}

Simone Luciano Vargas*

Resumo: No presente artigo, faz-se uma reflexão sobre as obras Transplante de menina, de Tatiana Belinky, e No exílio, de Elisa Lispector. As obras apresentam diferenças estruturais, como o foco narrativo, embora apresentem características autobiográficas. O método de análise foi o cotejamento das duas obras, de modo a perceber as semelhanças e diferenças entre as vivências das autoras. Quanto à temática, ambas representam a experiência do processo diaspórico pela criança migrante e a integração ao país de acolhida. Como resultado, obteve-se que as condições socioeconômicas e a formação cultural das famílias foram decisivas para a adaptação das autoras à cultura brasileira.

Palavras-chave: Criança migrante. Migração. Exílio.

\section{INTRODUÇÃO}

m pleno século XXI, vários países têm vivenciado as causas e consequências de uma migração em massa. No entanto, a situação da migração não é nenhuma novidade, posto que no século passado, também devido às duas guerras mundiais e à Revolução Russa, populações migraram da Europa Oriental para outros continentes. Por isso, neste artigo, proponho a análise reflexiva de duas obras, consideradas de cunho autobiográfico, que tratam sobre o tema de refugiados no século XX, são elas: Transplante de menina (2003), de Tatiana Belinky, e No exílio (1971), de Elisa Lispector. As obras evocam as memórias de criança das autoras no período em que viveram na Europa até a migração para o Brasil. Elas testemunharam eventos que marcaram o século XX, como a Revolução Russa e a perseguição aos judeus, e que as tornaram crianças migrantes. Antes desses eventos, elas tinham uma vida 
considerada apropriada para uma criança; com os adventos, o cotidiano infantil mudou: foi preciso assumir responsabilidades, passar por privações e enfrentar situações-limites. Para a análise, importa os eventos que as autoras experienciaram durante a infância.

Transplante de menina tem por temática as memórias da escritora Tatiana Belinky: da infância, na Letônia (Rua dos Navios, Riga), à pré-adolescência, dos 10 aos 13 anos de idade, no Brasil (Rua Jaguaribe, São Paulo), tempo histórico que corresponde de 1919 a 1933. Em outubro de 1929, a família Belinky migrou para o Brasil. A partir desse momento, ela narra o processo de adaptação, que considerou traumática.

Em No exílio, a escritora Elisa Lispector trata da perseguição aos judeus-ucranianos que, sob a constante ameaça dos pogroms ${ }^{1}$, resolvem migrar para a América. O romance não é linear, mas é possivel organizar os eventos temporalmente com base nos fatos históricos mencionados. Dessa forma, o tempo inicia com a Revolução Russa de 1917 e termina com o reconhecimento do Estado Judeu em 1948. A personagem Lizza, já adulta, durante uma viagem de trem, recorda o êxodo de sua família quando ainda era criança. Assim, o romance traz no enredo a fuga da aldeia Gaicin, na Ucrânia, a passagem por várias cidades incluindo outros países, como Moldávia, Romênia e Hungria -, as dificuldades a que foram submetidos, e a chegada e a integração ao Brasil.

As duas autoras são de origem judaica, embora Belinky fosse uma judia-russa-letã e Lispector, judia-ucraniana. O ano de migração também difere entre elas: Lispector chega ao Brasil em 1922, e Belinky, em 1929. Os motivos da migração são as dificuldades político-econômicas que os países da Europa Oriental enfrentaram no início do século XX e o recrudescimento da perseguição judaica.

\section{POR QUE ESCREVER}

Nem todos os autores de narrativas de memória justificam o que os leva a escrever suas vivências. No entanto, é possivel inferir a respeito. Devido à origem judaica das escritoras Tatiana Belinky e Elisa Lispector, é possivel pensar que os motivos que as levaram a narrar suas experiências não são diferentes dos que levaram vários sobreviventes da Shoah a narrar as experiências nos campos de concentração. Embora as obras selecionadas não tratem dos campos de extermínio, as duas Guerras Mundiais, a Revolução Russa e os regimes totalitários - nacionalismo-socialismo e comunismo - repercutiram na vida das populações, gerando situações que impunham o terror sobre as pessoas, obrigando-as à migração em massa. Nesse contexto, os judeus foram vítimas de pogroms por lhes serem imputados os problemas político-econômicos pelos quais passavam os países da Europa Oriental na primeira metade do século XX.

Tatiana Belinky (2003, p. 160), no posfácio, considerou suas memórias como um "bate-papo" com leitores brasileiros e estrangeiros, filhos e bisnetos, reconhecendo o Brasil como um país de acolhida. No entanto, escrever uma autobiografia e publicá-la foge do âmbito familiar, é uma ação que requer pesquisa e

1 Palavra russa para nomear ataques violentos às comunidades judaicas nos séculos XIX e XX, quando moradias, comércios e bens foram destruídos e judeus, assassinados. 
dedicação, além de trazer à tona situações traumáticas que se acreditavam esquecidas. É o medo do esquecimento que faz que pessoas, geralmente numa idade avançada, revivam experiências traumáticas - que até então fizeram um esforço para esquecer. Um dos objetivos é que as gerações futuras tenham conhecimento do que se sucedeu e para que, talvez, a humanidade não repita os mesmos erros.

O romance No exílio apresenta um caráter autobiográfico, baseado nas experiências vivenciadas pela autora Elisa Lispector quando criança (WALDMAN, 2014). O gênero romance ficcional impossibilita qualquer justificativa em relação à escrita de suas memórias, mesmo porque a escolha pelo narrador em terceira pessoa distancia os eventos da subjetividade da personagem:

De qualquer modo, o resultado da escolha da terceira pessoa gera, de imediato, a contradição entre a firmeza do discurso e a mobilidade do vivido. A experiência do sofrimento se dissolve no relato, forçado a responder a uma convenção da escrita (WALDMAN, 2014, p. 12).

Dessa forma, a autora não justifica sua escritura, como em geral ocorre com as autobiografias. Contudo, é possivel inferir que tenha sido levada pelo dever de memória como tantos outros relatos de sobreviventes judeus, em virtude do tema e do tempo histórico da escritura. Para tanto, utiliza-se de recursos narrativos, como o in media res, visto que o romance inicia com a personagem Lizza divagando numa viagem de trem no ano de 1948. A partir da notícia da proclamação do Estado Judeu, ela passa a recordar o êxodo familiar. Desse ponto em diante, a composição textual passa a ser fragmentada por sucessivos flashbacks, ora rememorações de Lizza, ora do pai, como se houvesse uma memória dentro de outra, numa espécie de mise en abyme. O romance termina com a personagem no trem retornando à sua casa após reclusão em uma clínica.

Ao fazer referência às situações traumáticas, individuais e coletivas, as autoras resistem ao esquecimento, comum entre aqueles que vivenciaram situações-limites:

O longo silêncio sobre o passado, longe de conduzir ao esquecimento, é a resistência que uma sociedade civil impotente opõe ao excesso de discursos oficiais. Ao mesmo tempo, ela transmite cuidadosamente as lembranças dissidentes nas redes familiares e de amizades, esperando a hora da verdade e da redistribuição das cartas políticas e ideológicas (POLLAK, 1989, p. 5).

Publicar as memórias, seja em um romance, seja em uma autobiografia, é contestar o status quo do discurso oficial, o que não deixa de ser um ato de coragem.

\section{INFÂNCIA NA EUROPA ORIENTAL}

Ser criança está relacionado ao construto social da infância em diferentes temporalidades e sociedades. Se na Idade Média, segundo Ariès (1981), não se considerava a existência de um período transitório entre a infância e a fase adulta - concepção de que a criança era um adulto em miniatura -, atualmente considera-se que diferentes fases fazem parte do desenvolvimento humano, como a infância, a adolescência, a vida adulta e a velhice. Para este artigo, impor- 
ta a concepção de infância como se concebe na atualidade, "[...] como uma construção social [...] que se transforma com o passar do tempo e, não menos importante, varia entre grupos sociais e étnicos dentro de qualquer sociedade [...]" (HEYWOOD, 2004, p. 21). Visto por esse ângulo, uma criança de classe média tem uma formação diferente da que provém da classe trabalhadora, uma menina é criada diferente dos meninos, as experiências de uma criança judia são distintas da católica ou daquela que é proibida de exercer qualquer tipo de religião etc. Portanto, os aspectos sociopolítico-econômicos influenciam na construção identitária da criança, obrigando-a a responder de acordo com os estímulos externos.

Segundo Heywood (2004, p. 2),

[...] qualquer ideia a respeito de uma criança puramente 'natural' se torna dificil de sustentar uma vez que se compreenda que as crianças se adaptam prontamente a seus ambientes, o produto de forças históricas, geográficas, econômicas e culturais diversificadas [...].

Embora as autoras fossem de origem judaica, elas provinham de classes diferentes, cujos pais tiveram oportunidades distintas de formação. Isso diz muito ao compararmos suas trajetórias e suas infâncias, posto que o bem-estar da criança está relacionado à situação socioeconômica familiar. Nesse sentido, crianças podem ter diferentes infâncias.

Em Transplante de menina, Belinky organiza sua autobiografia em duas partes: o antes e o depois da migração. Na primeira, apresenta os seis anos iniciais de sua vida, o que se considera atualmente como primeira infância. A narradora-personagem descreve sua vida com os pais em Riga, na Letônia, e reconhece que levava a vida de uma criança de classe média: "Era gostoso sair para a neve, acompanhados pela nossa Fräulein, a governanta alemã, respirar o ar geladinho, passear no parque puxando o nosso trenozinho, descer com ele as rampas suaves do jardim público" (BELINKY, 2003, p. 13). A proteção que usufruiu durante sua primeira infância foi possivel porque os pais migraram de Moscou para Riga quando Belinky tinha apenas um ano de idade, caso tivessem permanecido na Rússia poderiam ter passado pelas mesmas situações-limites que a família de Lispector. Além disso, os pais de Belinky provinham de uma família judia abastada, cujos pais tiveram acesso à universidade, beneficio permitido a poucos judeus, visto que as leis da Rússia czarina restringiam o acesso dos judeus à educação.

Segundo Arendt, duas décadas antes do início da Primeira Guerra Mundial (1914-1917), período descrito como a idade de ouro da segurança, o antissemitismo havia dado uma abrandada:

Os judeus iludiram-se mais com as aparências da idade de ouro da segurança do que qualquer outra facção de povos europeus. O antissemitismo parecia pertencer ao passado; quanto mais os governos perdiam em poder e prestígio, menos atenção davam aos judeus (ARENDT, 1989, p. 72).

Isso em parte explica por que os pais de Belinky tinham formação universitária: a mãe era formada em Odontologia, e o pai não tinha concluído o curso de Psicologia devido à deflagração da guerra.

O pai de Lispector também sonhara com a vida universitária, pois 
[...] trazia em si a vocação para a ciência. A matemática e a física apaixonavam-no, mas, em todas as suas iniciativas, deparava sempre com a barreira inexpugnável - o estigma de ser judeu. Judeus havia que cursavam universidades, sim, mas só os que tinham recursos e se transferiam para o estrangeiro (LISPECTOR, 1971, p. 51).

Ou seja, o fato de partilharem da mesma etnia não significava que tivessem as mesmas oportunidades ou estivessem sujeitos às mesmas restrições durante o governo monárquico (ARENDT, 1989).

Para a família Belinky, com a perseguição à classe burguesa e aos que possuíam alguma propriedade, a saída foi retornar à Letônia, posto que ali estariam entre familiares e fora de alcance dos bolcheviques. Durante dez anos, os Belinky viveram na Letônia até se sentirem forçados a migrar. Devido ao tratado de paz de Brest-Litovski, firmado em 1918, o governo russo abriu mão temporariamente dos territórios dos países bálticos (Letônia, Lituânia e Estônia) a favor do governo alemão. Graças à derrubada da monarquia alemã (Revolução Alemã, em 1918) e à assinatura do armistício, os países bálticos foram considerados independentes (STEVENSON, 2016).

Em No exílio, a personagem Lizza, adulta, rememorou o êxodo familiar. A narrativa contém acontecimentos sucedidos antes mesmo de seu nascimento o que justifica a escolha do narrador em terceira pessoa, que privilegia o ponto de vista de Pinkhas, o pai, na maioria das vezes, como foco narrativo. É pela rememoração paterna que se apresenta a formação da família nuclear: o casamento arranjado, o trabalho como caixeiro viajante, as idas à sinagoga, os rituais judaicos. Isso antes da Revolução Russa obrigá-los a migrar. A primeira vez que Lizza foi mencionada, já constava como a mais velha de três irmãs. As outras aparições indicam que ainda se encontrava na primeira infância, embora não seja possivel precisar a idade. As rememorações de Pinkhas, do lar harmônico, junto da esposa Marin e das filhas, segundo a tradição judaica, serve de contraponto à peregrinação que se impuseram ao saírem da cidade de Gaicin. A família de Lispector se apresenta numa perspectiva da micro-história, já que representa o que muitas famílias judaicas passaram nesse período da história da Rússia.

A Revolução Russa mudou consideravelmente a rotina da família de Lizza:

1917. Fadiga. Exaustão. Campos abandonados. Estradas obstruidas. Quebranto de forças e esperanças sumidas. E por toda parte uma dolorosa fome de pão e de sossego - pão, para saciar as ânsias do corpo, sossego e esquecimento para apagar as amarguras da alma.

A guerra, no entanto, continuava a devorar homens. Essa guerra, que os arrancava brutalmente dos campos e lares, já se estava tornando assaz cruenta, demasiado voraz (LISPECTOR, 1971, p. 29).

O romance No exílio apresenta uma intima relação entre os conflitos civis russos e a consequência destes na vida das comunidades étnicas, neste caso, a comunidade judaica. A Revolução Russa foi uma disputa civil pelo governo do Império Russo, enfraquecido devido à Primeira Guerra Mundial: "A Revolução de Fevereiro de 1917, que derrubou a dinastia dos Romanov, foi a explosão espontânea de uma multidão exasperada pelas privações da guerra e pela manifesta desigualdade na distribuição de sacrificios [...]” (CARR, 1977, p. 88). Aos judeus 
eram impostos vários sacrificios, dentre eles o alistamento obrigatório. Em tempos de guerra, os soldados judeus eram posicionados na linha de frente. Com a desorganização do novo governo, ainda em combate com as dissidências regionais, a situação dos judeus não melhorou. Os pogroms persistiam, já que a população via os judeus como os causadores das dificuldades pelas quais passavam.

\section{Criança migrante}

O corpus selecionado põe ênfase nas experiências vivenciadas na fase infantil das personagens. É importante frisar que os eventos passam por um filtro, visto que as autoras, adultas, os veem a partir do tempo presente da escrita, o que implica uma reconstrução da memória: "[...] a lembrança é uma reconstrução do passado, com a ajuda de dados tomados de empréstimo ao presente e preparados por outras reconstruções feitas em épocas anteriores e de onde a imagem de outrora já saiu bastante alterada" (HALBWACHS, 2003, p. 91). Ou seja, os eventos são rememorados; entretanto, com o tempo transcorrido e o ponto de vista do adulto, passam por um processo de reflexão e justificação que não ocorreria caso ainda fossem crianças. Além disso, "a percepção de se estar vivendo o exílio nem sempre coincidiu entre os exilados" (ROLLEMBERG, 1999, p. 90), ou seja, exceto pelo exilado político, os outros emigrantes podem sentir o desterro como um exilio, ou não. Belinky via a sua migração como um transplante, Lispector como um exílio, sentimento visivel já na escolha do título das obras. O fato é que ambas trazem o tema da migração e o que isso significou para suas vidas na infância, além da contribuição que isso pode dar para o conhecimento de mundo de seus leitores.

Os conflitos mundiais, as revoluções e suas consequências - como a fome, o desemprego e até a perseguição político-religiosa - foram motivadores importantes para que famílias inteiras migrassem:

Nos tempos de antes da revolução, não era qualquer um que partia para a América. Faziam-nos os aventureiros, ou os que fugiam ao sorteio militar. Mas um homem que tivesse família, e um nome por que zelar, dar-se a tais aventuras [...] (LISPECTOR, 1971, p. 50).

Antes mesmo da Primeira Guerra Mundial, já ocorria a migração de judeus para países do continente americano, com o fim da guerra esse número teve um aumento considerável.

No momento que a migração passou a ser uma questão de sobrevivência para a familia Lispector, ela não foi mais vista como uma aventura, mas como uma necessidade:

- Marin, não se pode viver disto, é preciso começar tudo de novo. Agora falavam nele as esperanças do verdor de seus anos, tantas e tantas vezes frustradas. [...] Marin, aqui o nosso mundo acabou. Desmoronou-se. Aqui nossa geração não terá mais paz nem alegria (LISPECTOR, 1971, p. 50).

As palavras de Pinkhas à Marin antecipa o destino dos judeus na Ucrânia, pois, da sua geração, os que sobreviveram aos pogroms tiveram de enfrentar a ocupação alemã e a Shoah. Nesse sentido, as famílias Belinky e Lispector, mesmo com todos os traumas advindos, somente sobreviveram à perseguição nazista porque os pais tomaram a decisão de emigrar com a família. 
Quando a saída do país natal é voluntária, em geral, os imigrantes sonham em retornar à terra de origem, pois "é mais suportável imaginar o exílio em um tempo passageiro, acreditar que o retorno será breve” (ROLLEMBERG, 1999, p. 29). Contudo, uma situação que se planejava provisória pode se tornar permanente. Entretanto, não se pode dizer o mesmo a respeito dos imigrantes de origem judaica procedentes da Europa Oriental no século XX, pois a saída se devia à perseguição étnica e religiosa. Com a mudança dos governos monárquicos para o nacional-socialismo (nazismo) e o comunismo, a permanência de judeus nos países de território russo e alemão passou a ser arriscada, de modo que migrar se tornou uma questão de sobrevivência. Embora acalentassem a esperança de voltar, com a permanência dos governos autoritários e o enraizamento familiar no Brasil, a sua concretização ficava mais distante: "O que não podiamos imaginar é que acabaríamos ficando no Brasil para sempre - para nossa grande sorte e mesmo salvação" (BELINKY, 2003, p. 52). Portanto, aqueles que retornaram à Europa, por não suportarem o desterro, foram vítimas da Shoah.

O destino de Lizza e das irmãs, bem como de Belinky e dos irmãos, estava atrelado ao dos adultos, ou seja, as crianças não tinham escolha, os pais que decidiam a viabilidade do empreendimento, se migravam ou ficavam. Para Lizza, a mudança não se apresentava como algo positivo, não via como uma aventura pela qual ansiasse, pelo contrário, o sentimento era de perda e de caos ao ver sua casa sendo desprovida da mobilia e as pessoas circulando como se estivessem numa estação de trem.

Como os adultos são responsáveis pelas decisões, é presumível que as necessidades das crianças migrantes estejam em segundo plano. Com a mudança, iniciava-se o processo de desenraizamento - desapegar-se dos bens e dos amigos que ficaram - e antecipava a vida de judeus errantes, indo de aldeia em aldeia, até finalmente partirem para o Brasil.

A reação de Tatiana Belinky sobre a migração foi diferente: para ela, era uma aventura viajar para o Brasil num transatlântico. Os motivos pelos quais deveriam migrar não foram discutidos com as crianças; mas, segundo Belinky, era perceptivel a estas que havia mais a ser dito: "As razões dessa aventura eram para nós, crianças, muito nebulosas, a gente só percebia vagamente que havia no ar certa tristeza, apesar da 'fachada' otimista ostentada por papai e mamãe" (BELINKY, 2003, p. 52). Além disso, houve um planejamento familiar: o pai foi três meses antes, depois, a mãe com as crianças. Não passaram pelos mesmos reveses que Lizza e a família, embora os motivos da partida fossem tanto politicos quanto econômicos, e tivessem chegado ao Brasil "praticamente com a roupa do corpo" (BELINKY, 2003, p. 52).

Belinky não fez referência a sua aparência física, mas subentende que era bem alimentada ao afirmar que no Brasil os alimentos eram baratos e fartos. Já a personagem Lizza é apresentada com um aspecto doentio: "Em frente à Marin estava sentada Lizza, o rosto magro de tez esverdeada, à claridade tênue da manhã [...]" (LISPECTOR, 1971, p. 57, grifo nosso), pois as condições adversas do percurso influenciam no desenvolvimento fisico e emocional da criança migrante. Assim como os pais sentiam no corpo as consequências da vida errante que empreenderam, é evidente que as crianças, de constituição frágil, também os sentiriam. A desnutrição das crianças é uma consequência, visto que o alimento é parco, na maioria das vezes fornecido por alguma instituição de assistência. 
Portanto, o aspecto físico de Lizza não se assemelhava ao aspecto de uma criança que vive num lar protegido, sem grandes tribulações. Pelo contrário, a menina ainda assumiu as responsabilidades da mãe devido à doença desta:

[...] Para com Lizza tinha uma atitude diferente. Afagava-lhe silenciosamente a cabeça, às vezes apenas se detendo a fitar-lhe o rosto magro, os membros finos e longos, a boca sem expressão definida. Os olhos selvagens. Ela era feia, desgraciosa, e aquilo the doía. Doía-lhe, sobretudo, o seu ar prematuramente grave marcado pelos pesados encargos; e à medida que a moléstia de Marin progredia, era para Lizza que se iam passando as responsabilidades e os quefazeres domésticos (LISPECTOR, 1971, p. 73).

Nesse sentido, a atitude paterna em relação a ela era diferenciada, pois o pai tinha consciência de que a formação de Lizza tinha sido afetada pela situação que a família estava passando, não somente física, mas também identitária. No entanto, embora a situação de passar à filha os encargos da mãe lhe doessem, ele não tinha escolha. As outras filhas, Ethel e Nina, eram muito pequenas para que pudessem dividir o fardo, de modo que a situação de Lizza configura-se como tendo uma infância negada. Acredita-se, no mundo ocidental, que a infância é uma fase em que a criança deve ser protegida e não deve exercer atividades que vão além de suas capacidades físicas. Portanto, as crianças podem executar pequenas atividades domésticas e, à medida que crescem, as tarefas vão se modificando conforme seu tamanho e experiência (HEYWOOD, 2004). Assim, as crianças são responsáveis pela execução de algumas atividades, desde que essas não se configurem como trabalho infantil. No caso de Lizza, com a mãe hospitalizada, ela ficava a cargo de todas as tarefas domésticas, do cuidado das irmãs menores, além de permanecer na fila das instituições assistenciais que forneciam alimentos aos necessitados.

Nos momentos em que o narrador direciona seu olhar para Lizza, é possivel verificar como o fato de ter assumido os afazeres da mãe influenciavam sobre o seu espírito: "Não raro ia além do que esperavam dela, parecendo experimentar um secreto prazer em dar de si. Era a compensação para os seus tenros anos de sem alegria nem infância” (LISPECTOR, 1971, p. 73, grifo nosso). Embora o foco esteja centrado em Pinkhas, o narrador entrevê ao leitor os sentimentos de Lizza, mesmo que ele não possa garantir de que seja realmente isso. É importante retomar nesse momento que, como mencionado no início deste artigo, se está trabalhando com a hipótese de que Lizza personifica a autora Elisa Lispector quando criança (WALDMAN, 2014). No compromisso de manter o foco narrativo escolhido para a fase infantil, o narrador mantém o distanciamento da subjetividade de Lizza quando criança.

Portanto, o narrador confirma que a personagem não teve infância e que, por parte dela, haveria a necessidade de uma compensação por essa perda. Nesse sentido, a aceitação paterna seria uma forma de compensá-la. Depois de terminar as tarefas domésticas, era com pai que ela permanecia, ainda que o local onde ele trabalhasse fosse insalubre. No romance, são vários os indícios de que Lizza aspirava à aprovação paterna, por isso, a reação do pai sobre seus atos lhe importavam.

Belinky (2003, p. 88), desde o momento em que saiu da Letônia, também passou a cuidar dos irmãos menores, sendo uma de suas tarefas no Brasil: 
[...] (A era da Fräulein havia terminado...) Mais ainda, eu não só podia, como devia levar o meu irmãozinho caçula, então com um ano e meio de idade, a passear - às vezes a pé, outras de carrinho, mas sem sair da calçada, naturalmente. E eu gostava de fazer isso [...].

No entanto, ao contrário de Lizza, as tarefas que executava não poderiam ser enquadradas como trabalho infantil. O pai de Belinky, desempregado, auxiliava nas tarefas domésticas; enquanto a mãe, além de cozinhar e fazer as compras na feira, como prática licenciada (dentista), atendia aos clientes no consultório. Ou seja, as tarefas eram divididas entre os integrantes da casa segundo suas capacidades, aos adultos cabiam as tarefas mais penosas e perigosas.

\section{A condição judaica}

No exílio apresenta os acontecimentos históricos que ocorreram no início do século XX na Ucrânia. Em 1948, ano em que o livro foi publicado, os fatos narrados ainda não haviam tido a atenção que recebem atualmente, ofuscados pela Shoah impetrada pelos alemães. A obra claramente tem a intenção de dialogar com a história dos judeus durante esse período obscuro da diáspora judaico-ucraniana.

Os pogroms, como o que foi descrito na narrativa, não eram eventos fora do comum para a Rússia czarina, principalmente na Ucrânia, onde vários ocorreram incentivados até pelas autoridades locais. Os mais conhecidos, ocorridos no século XX, são os de 1905/1906 - período em que o governo czarista instigou contra os judeus a população insatisfeita com seu governo - e os da Revolução Russa, já no governo bolchevique.

A menção aos pogroms, do início do século XX, assunto pouco tratado pela história na década de 1940, e suas consequências revela um tom de denúncia das barbáries, às quais os judeus estavam sujeitos muito antes da Segunda Guerra Mundial. O registro, no romance, foi a forma de a autora contribuir para o não esquecimento do que foi feito ao povo judeu. A reconstrução da memória é uma forma de ressignificá-los e de contrapô-los aos discursos oficiais que procuram, segundo os interesses do momento, negar certos eventos. No livro As origens do totalitarismo (1989), a autora Hanna Arendt se refere ao protecionismo voltado aos judeus úteis ao Estado e à desconfiança que os judeus abastados tinham da ralé e do povo. A filósofa não menciona a perseguição judaica e os pogroms na Rússia, mas é de se inferir que, quando o Estado retira sua proteção e ainda incentiva a violência aos judeus, a consequência seria esta: pogroms executados por antissemitas, como prenúncio do genocídio da Segunda Guerra Mundial.

Contudo, como fazer menção não é suficiente para demonstrar a barbárie, em No exílio há uma descrição de um pogrom na cidade onde Lizza morava, durante a Revolução Russa, com a descrição das atrocidades que um ser humano é capaz de fazer contra a vida de outro. São eventos que as vítimas não conseguem apagar de suas memórias, como o que ocorrera a uma vizinha: "[...] Penduraram-na na bandeira da porta, de mãos e pés atados, e obrigaram-na a presenciar tudo, até o fim. Daí para cá está assim. Não vê nada, não ouve, não entende coisa alguma. Não fala, nem sequer chora” (LISPECTOR, 1971, p. 37). Essas situações-limites geram traumas recalcados na memória que trazem consequências negativas para a vida das pessoas. 
Lizza, como era a mais velha das irmãs, presenciara algumas ocorrências na aldeia e tentava compreender o motivo dos pogroms. Apesar da idade, já percebia que somente a comunidade judaica estava sendo vitimada, enquanto as outras etnias passavam incólumes aos saques e aos assassinatos. É dificil compreender o que não tem lógica, principalmente aquilo que não faz parte do que lhe é conhecido, como o ódio do qual os judeus foram alvo. As explicações dos adultos, por serem limitadas, mais confundiam que esclareciam as questões da menina: "Mas isso não explicava tudo, pois, se estes são algozes, que fazem os que não são? Que fazem que não vem em nosso auxílio?” (LISPECTOR, 1971, p. 41).

A perseguição aos judeus é histórica. Algo que ocorre desde a antiguidade e faz parte das histórias e celebrações judaicas. Nesse sentido, o romance também dialoga com a tradição ao retomar a história do êxodo na Idade Antiga, como a repetição do que estava sucedendo às personagens no século XX. A errância que os hebreus foram submetidos quando peregrinaram pelo deserto durante quarenta anos, eles estavam vivenciando na Ucrânia: "E o temor, o temor desgraçadamente justificado que há milênios persegue os filhos de Israel, acorda no espírito dos emigrantes, e é pior que a fome, a sede, o frio. Pior que o quebranto do corpo e da alma" (LISPECTOR, 1971, p. 52). O temor como uma herança epigenética, que "acorda no espírito", como uma maldição que de tempos em tempos vem aterrorizá-los.

A celebração da Pessach (Páscoa judaica) é uma forma de reviver o que os antepassados tinham experienciado. A família Lispector, mesmo sem poder seguir o ritual como fora prescrito, mantinha-se fiel à tradição. Não é por acaso que o capítulo em que mostra a celebração da saída do Egito contém como epígrafe o ordenamento do estatuto perpétuo, independentemente das circunstâncias. Esse fato evidencia a situação dos judeus perante a tradição, pois as circunstâncias os faziam esmorecer na fé, deixando de lado até mesmo aquilo que lhes era mais caro: “- Não pude arranjar nada que servisse de korbanot nem de kharosset. Só consegui raiz amarga para o maror. Aves, vinho, nozes... penso que ninguém mais se lembra o que isso vem a ser. - Falava com voz arrastada" (LISPECTOR, 1971, p. 65, grifo nosso). A própria Marin, ao fazer os preparativos, não os fazia com a mesma alegria e harmonia de movimentos de antes. Dessa maneira, o que esse episódio reforça é o espírito alquebrado do judeu errante. Esse momento também é representativo, pois indica como a tradição é passada às gerações seguintes.

Belinky também teve suas experiências com a tradição judaica ainda na Letônia; assim como Lizza, ela frequentava com a família a sinagoga de sua cidade: "Em matéria de templos eu só conhecia o interior da bela sinagoga de Riga, com seu altar de cortinas e os grandes rolos da Torá, com uma luz maravilhosa filtrando-se pelos vitrais [...]" (BELINKY, 2003, p. 104). O tom melancólico se justifica porque, no tempo da escrita, a sinagoga já não existia mais:

A velha sinagoga de Riga, onde iria perecer, assassinada pelos nazistas, junto com muitos outros, grande parte de nossa numerosa família, velhos e jovens, mulheres e crianças. As mesmas crianças com quem eu e meu irmão brincávamos tanto [...] (BELINKY, 2003, p. 104).

Assim como milhares de judeus que se dispersaram pelo globo, Belinky também perdera familiares no exterminio impetrado pelos alemães na Segunda Guerra Mundial. O incêndio à Sinagoga Grande Coral de Riga, com judeus sen- 
do incinerados, é um fato que faz parte da história judaica na Letônia. Fazer menção a esta sinagoga, em especial, soa como lamento e denúncia da crueldade humana.

Embora o objetivo do extermínio fosse apagá-los da memória, as pessoas se vão, mas ficam as lembranças e o registro de sua existência, como em Transplante de menina:

E no videotape da minha memória permanecem gravados, como quadros vivos, alguns momentos recorrentes da nossa vida com vovô e vovó. Recorrentes e como que "encantados": vovó cobrindo o rosto com as mãos, lenço de seda na cabeça, pronunciando comovida a bênção das velas do shabat, ao anoitecer da sexta-feira. Vovô "presidindo" a compridissima mesa do seder, a ceia da páscoa judaica, na qual ele relatava, para a grande família reunida, com sua voz grave e modulada, a história emocionante da libertação do povo hebreu, da escravidão dos faraós do Egito [...] (BELINKY, 2003, p. 23).

Mais uma vez os rituais judaicos, como o Shabat e o Pessach, apresentam-se como a forma de transmissão da cultura judaica às novas gerações. Além disso, eram momentos especiais que reuniam a família, mostra de união familiar e de mesma fé. Longe dos familiares, esses momentos revivificados, por meio das contínuas rememorações, contrapõem-se à vida solitária que vivenciavam no Brasil. O que contribui para lhes aumentar a aura de encantamento, tornando esses eventos sacralizados, como imagem viva e perene, que podem ser invocados. A recorrência às lembranças dos familiares que foram deixados no país de origem também faz parte da vida de uma criança migrante.

\section{A condição de estrangeira}

Em No exílio, a peregrinação da família de Lizza pelos países da Europa Oriental já era o processo de desterritorialização que se iniciava, visto que o "desenraizamento do universo de referências" (ROLLEMBERG, 1999, p. 132) já estava em curso. Desse modo, ainda na Europa, já se encontravam na condição de estrangeiros, pois peregrinavam por países estranhos, onde era dificil ao pai arrumar emprego ou empréstimo para comprar mercadorias e revendê-las para exercer o comércio. Havia o desafio da subsistência em cada cidade pela qual passavam, cabia a Pinkhas arrumar meios de prover uma moradia e uma parca alimentação.

Diante da subsistência, as vestimentas não eram consideradas artigos de primeira necessidade. Com o crescimento físico, Lizza necessitava de roupas que lhe coubessem, mas a condição da família era de indigência. A forma como Lizza se apresentava em público, de vestes surradas e curtas, acabava por lhe trazer outros dissabores, como atrair a atenção daqueles que não mereciam confiança. A personagem sentia vergonha e dor, pois tinha percepção de sua situação, suficientemente para causar uma desestruturação emocional, que se apresentava no seu semblante e comportamento: "Era acanhada e triste, desajeitada de movimentos, os olhos selvagens [...]” (LISPECTOR, 1971, p. 84). A situação de penúria do pai também a afetava:

E, por entre bancas com roupas usadas, [...] dava com o pai sentado diante de uns caixotes toscos à guisa de balcão, e sobre eles um amontoado de sapatos ordinários. E aquilo lhe doía. Era como se o tivessem obrigado a representar de trapeiro [...] (LISPECTOR, 1971, p. 84-85). 
Lizza se comovia com a situação do pai no mercado, mas ainda não tinha total entendimento, pois não compreendia o motivo de ele se sujeitar à situação. Sabia que havia outros modos de vida que não a sua, via isso refletido nos manequins das lojas que a faziam devanear em frente às vitrines, nos habitantes das cidades que os tratavam com indiferença ou como indigentes. Os primeiros anos da família Belinky no Brasil também foram de penúria, mas não se comparavam à situação vivenciada pela família de Lizza na Europa.

Depois, com a impossibilidade de ficar por muito tempo na mesma cidade, logo tinham de ir para outra e outra, de modo que percorreram as grandes cidades da Moldávia, Romênia e Hungria, passando por dificuldades semelhantes às dos antepassados: não tendo pouso certo, em um constante recomeçar. Em No exílio, o Brasil se apresentava como um país no qual havia a possibilidade de se ter uma vida estável, sem os constantes deslocamentos que estavam sujeitos na Europa Oriental, por isso, o processo de desterritorialização atingiu o ápice com a integração à cultura brasileira.

Naquela época, década de 1920, o navio era o meio de transporte para atravessar o oceano Atlântico. Em ambas as obras, há uma descrição sobre as condições de viagem dos imigrantes e a percepção das meninas sobre o traslado. Em Transplante de menina, Belinky traz uma visão mais positiva sobre a viagem e é um dos pontos altos da narrativa:

Vimo-nos de repente no meio de pessoas bem diferentes de nós, no aspecto, na roupa, nos modos de falar e se conduzir, e só isso já era o começo de uma aventura. [...] O capitão olhou para nós e logo percebeu que aquela não era uma família de operários ou camponeses (BELINKY, 2003, p. 57-59).

A ênfase é na distinção de classes e na sociabilidade entre os passageiros no navio, perceptivel pela indumentária e pelo comportamento. Eles viajavam na terceira classe, como a maioria dos emigrantes vindos da Europa, mas o capitão do navio arrumou uma acomodação melhor para a família Belinky. Para as crianças, não acostumadas a conviver com camponeses e operários, tudo era novidade, assemelhando-se a uma grande aventura. Uma extraterritorialidade que logo terminaria, sem vínculos, tão logo eles chegassem ao Brasil.

O relato da travessia do Atlântico de Belinky se diferencia do relato de Lizza. Como emigrantes sem dinheiro, eles se alojaram no porão do navio:

No porão, o calor e o ar viciado sufocavam. [...] E quando uma ratazana enorme e lerda, os pequeninos olhos fuzilando por entre o pelo cinzento e repelente, passou sobre o travesseiro, roçando-lhe o rosto [de Lizza], toda a sua tensão nervosa explodiu em asco e revolta (LISPECTOR, 1971, p. 89-90).

Para ela foi mais uma lembrança triste para marcar uma existência infeliz. Esse trecho é representativo das condições insalubres dos navios que transportavam os emigrantes na época. Os ratos estavam tão acostumados com os intrusos que não tinham temor de andar sobre os passageiros, temporariamente próximos da mesma condição.

A chegada de Belinky ao Brasil se deu pelo Rio de Janeiro, assim, a vista da Baía da Guanabara foi uma imagem que lhe ficou na memória, pois se apresentava como um grande cartão-postal e um sinal de boas-vindas: 
Todo mundo correu para as amuradas, e ficamos olhando de longe aquela vista incomparável: a linha harmoniosamente curva da praia de Copacabana, toda faiscante no seu "colar de pérolas", como era chamada, carinhosamente, a iluminação da Avenida Atlântica (BELINKY, 2003, p. 63).

O Rio de Janeiro a impressionou pelas belezas naturais que lhe são peculiares. Mas essa não era a única cidade que os navios de imigrantes aportavam, pois "muitos deles aportaram no Rio de Janeiro, em Santos (São Paulo) e no Recife (Pernambuco); foram estes os portões de entrada para o Brasil" (BLAY, 2013, p. 51). Houve aqueles, como o da família de Lizza, que, depois de o navio atracar em Recife, aportaram em Maceió (Alagoas).

A condição de estrangeiro se revela no estranhamento com os costumes do país de acolhida. Como criança, Belinky estranhou as calças curtas que os meninos usavam na época para diferenciá-los dos adultos; pois, aos seus olhos, os meninos pareciam anões. Esse tipo de roupa não era prerrogativa do Brasil; em países do Ocidente, como França e Estados Unidos, os meninos também usavam calças curtas como símbolo de um período de transição, já a calça comprida era sinal de amadurecimento, o ingresso visivel a uma nova fase da vida (HEYWOOD, 2004). Entretanto, o estranhamento era mútuo: "Mas os meninos caçoavam de nossos trajes, chamavam meu irmão de mariquinhas, perguntavam se aquilo era fantasia de carnaval" (BELINKY, 2003, p. 84). Isso se dava porque as crianças estrangeiras recém-chegadas, geralmente, em completa penúria, ainda vestiam os trajes típicos de seus países. Além disso, a Rua Jaguaribe já era ocupada por operários italianos, cujos filhos consideravam os demais estrangeiros intrusos: "Mas naquele tempo e naquela rua nós éramos os diferentes, e sofríamos com as zombarias das outras crianças: meu irmão - o do meio, o pequeno ainda não entendia nada - chegava a chorar por causa disso" (BELINKY, 2003, p. 85).

As memórias de Belinky sobre essa fase inicial de integração dão ênfase às perseguições que sofriam por parte das crianças da Rua Jaguaribe, julgando traumáticos os primeiros três anos vivenciados no Brasil. As crianças "sofrem fisicamente e emocionalmente com a segregação, o preconceito, a desigualdade, as exclusões, as mudanças e as diferenças entre culturas. [Apesar disso] Têm que se adaptar aos diferentes mundos que os adultos escolheram [...]" (GOMES, 2011, p. 55). Além da perseguição, costumes, como a malhação de Judas no Sábado de Aleluia, cooperaram para o estranhamento à nova cultura:

Outra coisa que eu vi pela primeira vez na Rua Jaguaribe e que me assustou [...] foi no sábado de aleluia de 1930 o "alegre" ritual da malhação de Judas. [...] enquanto massacravam com paus e pedras um espantalho de forma humana, que acabavam enforcando num poste e "queimando vivo" diante dos meus olhos horrorizados. Para mim aquilo não era uma brincadeira, era, isso sim, um linchamento, um pogrom - simbólico, mas linchamento (BELINKY, 2003, p. 116).

O fato de Judas ter sido judeu contribuiu para comparar a celebração com os pogroms que ocorriam na Europa. Em Transplante de menina, não há a informação de que Belinky tenha sido vítima ou presenciado um pogrom, mas é de se considerar que os fatos ocorridos na Europa não eram desconhecidos da comunidade judaica no Brasil, visto que com a chegada de novos imigrantes, as notícias eram atualizadas. 
Enquanto a opção do pai de Belinky foi instalar a família na cidade de São Paulo, distante do Bom Retiro, bairro judeu, e longe de qualquer parente (havia um primo que morava no Rio de Janeiro), a família de Lizza instalou-se em Maceió, vivendo no início sob a tutela de parentes, a irmã e o cunhado de Marin. Embora vivessem próximos de pessoas conhecidas, de mesma etnia e mesma língua, a adaptação foi difícil. Após a alegria inicial ao encontrar um mundo novo, totalmente diferente do que estavam acostumados, principia-se a fase de adaptação ao calor sufocante, aos insetos, às doenças e às cobranças dos parentes.

O narrador se apresenta mais próximo à subjetividade de Lizza com a chegada da família ao Brasil, mas a apresenta em uma fase de transição, visto que ela ainda não tem o entendimento, ou a malícia, para compreender os sentidos por trás das atitudes dos adultos. No entanto, a menina pressentiu as más intenções da tia quando a levou com as irmãs para sua casa. A ideia era permanecerem ali enquanto o pai e a mãe, hospitalizada, estivessem fora. No entanto, a tia as instalou no quarto da empregada, que estava de "folga". As intenções da tia não são reveladas, mas pelo caráter avarento e soberbo que demonstrava, o leitor pode inferir que Lizza substituiria a empregada. Talvez seja isso que a intuição de Lizza a tenha advertido e a levado a retornar à própria casa na manhã seguinte.

Ainda como criança, a imaginação lhe era fértil e apresentava-se como recurso para escapar da realidade presente, para com ela, sempre hostil e cruel. Lizza construía um universo particular pela imaginação, ressignificando o cotidiano e os espaços, um meio de

[...] proteção, refúgio contra as exigências externas que atrapalham ou meio de se distrair quando se aborrece. [...] Ela experimenta suas forças novas. Exercita sua imaginação, assim como exercita os seus músculos, ou descobre ou constrói, pouco a pouco, os mecanismos lógicos (HELD, 1980, p. 45).

Belinky também devaneava num mundo próprio, interdito aos adultos. No entanto, diferente de Lizza, ela sempre tivera as histórias fantásticas contadas pelo pai ou os livros que alimentavam o seu mundo imaginário com novas personagens e aventuras, com a vantagem de que a aproximavam do imaginário russo e de idiomas conhecidos, o que amenizava a falta de sua terra natal. No Brasil, a imaginação se lhe apresentava como um ponto de fuga de sua condição de estrangeira:

E hoje posso dizer que isso [falar outros idiomas] me foi de imensa utilidade $e$ ajuda na vida em geral - sem falar na vantagem e no prazer de poder ler os meus amados livros no original [...]. E "viajando" mais depressa que qualquer foguete atômico: com a rapidez do pensamento (BELINKY, 2003, p. 30).

O ambiente escolar, para os estrangeiros, estava longe de ser um lugar tranquilo e acolhedor, tanto para Lizza quanto para Belinky (2003, p. 139):

Só que aquela bonita, rica, bem instalada e bem equipada escola não foi nada boa para nós, meu mano e eu. Ela representou mais um dos grandes traumas do nosso primeiro ano em São Paulo, e mesmo de toda a nossa vida de crianças.

Com a intenção de minimizar o choque cultural vivenciado pelos filhos, os pais os colocaram numa escola onde o ensino era todo ministrado em alemão. 
Escola severa em que eram comuns os maus-tratos, tanto por parte dos professores em aula quanto dos alunos nos recreios: "O que eu ouvi e aturei de xingamentos e desaforos naquele pátio, só eu sei: cheguei a ser acusada, em altos brados, até de ter crucificado Jesus Cristo..." (BELINKY, 2003, p. 140). No início do século XX, os estereótipos vinculados aos judeus na Europa já haviam migrado para o Brasil. O período histórico coincide com a perseguição aos judeus no Brasil impetrada por grupos antissemitas, talvez isso justifique a acusação dos colegas na escola. A acusação da crucificação de Jesus Cristo, por exemplo, marca diferenças não somente étnicas, mas também de crenças.

Quando chegou à escola, Belinky foi colocada numa classe adiantada, pois na Letônia chegou a frequentar uma instituição alemã. Mas o seu desejo era estudar numa escola em que as aulas fossem ministradas em português, pois já reconhecia a importância de aprender o idioma do país de acolhida. Depois de um incidente com uma das professoras, os pais transferiram os filhos para uma escola americana, o Mackenzie, onde Belinky concluiu os estudos.

A adaptação de Lizza também foi traumatizante. Nos recreios, longe da supervisão dos adultos, as crianças davam toda vazão à perversidade infantil:

- ca-de-a-do, repetia, pondo acento em cada sílaba, com medo de errar. A meninada ria, pulava em torno, uma puxando-lhe a saia, outro, o cabelo maltratado. Suportava, de dentes cerrados, contendo-se para não dar parte de fraca. Se chorasse, seria pior (LISPECTOR, 1971, p. 102).

A lingua, nesse momento, apresentava-se como uma barreira e uma arma que as crianças da escola usavam contra ela. O desconhecimento da lingua mantém o estrangeiro em desvantagem ao outro, pois não pode se comunicar. Essa dependência, de certa forma, infantiliza o estrangeiro, visto que tem de ser ressocializado, como uma criança se torna dependente da boa vontade daquele que o irá introduzir na nova cultura. Os tios de Lizza, Henrique e Dora, foram os guias no processo de integração da família Lispector, papel que eles aproveitaram para tirar vantagem.

Com a adolescência e a mãe hospitalizada, Lizza sentia a necessidade de uma presença feminina. A escolha da personagem foi pela companhia da tia, posto ser o adulto do gênero feminino mais próximo. Mas novamente essa a decepcionaria, pois não soube perceber as necessidades da menina: "Esperava, na sua fragilidade de galho tenro e receptivo, a experiência e a seiva que adviessem daquele tronco maciço e vivido" (LISPECTOR, 1971, p. 103). O narrador não somente constrói uma imagem de derrota, como também usa da prosopopeia para refletir os sentimentos da menina com relação a mais essa frustração: "Então voltava para casa com passos vagarosos, os ombros caídos, os olhos fitos na sombra alongada à sua frente que ia projetando o sol agonizante da tarde" (LISPECTOR, 1971, p. 103). Tal é a imagem construída que é possivel ao leitor perceber a dor de Lizza.

Belinky (2003, p. 157), ao entrar na fase da adolescência, também sentiu as mudanças físicas e emocionais:

Meus interesses começaram a mudar, junto com as mudanças que se processavam no meu corpo. As conversas entre as meninas estavam ficando diferentes, assuntos novos entravam nas conversas - que por sinal eu achava bastante maliciosas. 
Contudo, ao contrário de Lizza, Belinky não fugiu do convívio com as outras pessoas. Ela interagia com as jovens da sua idade, demonstrando mais confiança em si mesma. Lizza, pelo contrário, apresentava um comportamento retraído: "A alegria ruidosa das outras não a contagiava, mesmo quando se mostravam benévolas e condescendentes para com ela, a imigrante" (LISPECTOR, 1971, p. 103). Enquanto Belinky procurava se integrar à cultura brasileira, por meio de negociações transculturais com as crianças da Rua Jaguaribe e da escola Mackenzie, Lizza se afastava até mesmo daqueles que tentavam uma aproximação.

\section{CONSIDERAÇÕES FINAIS}

As memórias reconstruídas nas obras Transplante de menina, de Tatiana Belinky, e No exílio, de Elisa Lispector, evidenciam as experiências de crianças migrantes que deixam o país de origem com seus pais para se instalarem no Brasil. Ambas as autoras se utilizam de suas memórias de infância para a construção da narrativa.

No entanto, a intenção de Belinky é registrar essa fase de sua vida. Dessa maneira, a narrativa apresenta as características convencionadas para o gênero autobiográfico: narrativa retrospectiva, narrador-personagem não nomeado, ênfase na história pessoal. Além disso, Transplante de menina está estruturado em duas partes: a fase da infância vivida na Letônia e a adaptação no Brasil, o que lhe confere linearidade. No exílio apresenta uma proposta diferente, embora seja possivel associar o nome da personagem Lizza com o da autora e com fatos de sua vida pessoal, por isso se infere o cunho autobiográfico. Trata-se de um romance ficcional que se utiliza do in media res e o narrador em terceira pessoa para a construção narrativa. Os constantes flashbacks promovem uma narrativa fragmentada, numa estrutura mise en abyme, o que lembra as matrioskas, as tradicionais bonecas russas.

Pelo fato de ambas as narrativas terem por fundamento a memória individual, é possível considerá-las como híbridas, pois as fronteiras entre a ficção e a não ficção são difusas. Belinky afirma que sua narrativa é verídica, mas não considera que a memória possui lacunas e estas são preenchidas com a imaginação; enquanto Lispector, ao fazer ficção, estrutura a narrativa em fatos verídicos, tanto sócio-históricos quanto pessoais, como a situação diaspórica que ambas são obrigadas a experienciar.

A personagem Lizza, além de presenciar situações traumatizantes até para um adulto, foi lançada numa via de peregrinação em que a situação de indigência lhe parecia não ter fim. O Brasil, que representava o fim da peregrinação familiar, em um primeiro momento, não oferecia as condições necessárias para a reestruturação da família, em parte pelo espírito alquebrado do pai que não conseguia se impor à tirania dos cunhados. Dessa forma, a integração de Lizza, sendo a mais velha das irmãs, apresentava-se quase que impossivel, posto que para ela a situação em que a família se encontrava era de aprisionamento. Sob a tutela do pai, e este submisso às condições que lhe eram impostas, não havia muito o que ela pudesse fazer, a não ser assumir o lugar da mãe nas tarefas domésticas, abrindo mão de sua infância.

Tatiana Belinky rememora sua infância na Letônia, onde a vida se apresentava feliz, despreocupada, própria para o desenvolvimento de uma criança. Con- 
tudo, com a intensificação da perseguição aos judeus, a família migra para o Brasil. É aqui que ela sentiu as dificuldades familiares, tendo de auxiliar os pais nos cuidados dos irmãos e enfrentar a rejeição aos estrangeiros na Rua Jaguaribe e o antissemitismo na escola. Os três primeiros anos no Brasil marcaram a sua infância como um divisor de águas: num momento pertencia à classe burguesa na Letônia; em outro, disputava o espaço com filhos de operários italianos, sendo que estes se encontravam numa situação vantajosa, pois, embora estrangeiros, se sentiam donos da rua, já que se estabeleceram antes. As constantes disputas com as crianças da Rua Jaguaribe fizeram que Belinky negociasse o espaço com as outras crianças, sem nunca ser de fato aceita.

Nesse sentido, a condição de estrangeira de ambas serviu como um empecilho para uma integração harmoniosa, visto que desconheciam os costumes locais e a língua do país. No entanto, Belinky não se intimidava e persistia no objetivo de integrar-se à nova cultura. Lizza, como o pai, se submetia às circunstâncias, mantendo uma postura de apatia e resignação. "Ao chegar ao novo lugar, o adulto migrante não busca apenas emprego e a criança não deseja apenas se adaptar, ambos precisam compreender e aprender o movimento da sociedade da cultura" (GOMES, 2011, p. 48). Entretanto, a nova cultura é integrada à cultura de origem, e os novos sentimentos são influenciados pelas experiências já vivenciadas, traumáticas ou não. Dessa forma, o modo de sentir e agir pode se diferenciar mesmo em circunstâncias semelhantes, como a perseguição que sofreram na escola. Aqueles que aqui já estavam não se sentiam dispostos a partilhar o que conquistaram, e o antissemitismo que chegava ao Brasil foi mais um empecilho para o processo de integração. "É uma relação intensa e contraditória, pois é entrelaçada pelas dificuldades ou impossibilidades de perceber os reais elementos que transcorrem as práticas e as confrontações assíduas" (GOMES, 2011, p. 45).

A integração da criança migrante a uma nova cultura é dificil, pois são muitas as barreiras para ultrapassar a desconfiança do outro, mas quando o estrangeiro se fecha sobre si mesmo, a integração pode ser impossivel.

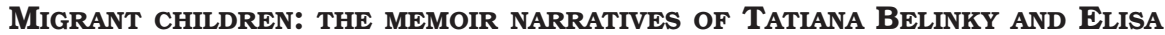 LISPECTOR
}

\begin{abstract}
In the present article, we conducted a reflection on the works of Transplante de menina, by Tatiana Belinky, and No exílio, by Elisa Lispector. Both works show structural differences, such as the narrative focus, despite presenting autobiographical characteristics. The method of analysis was the investigation of the two works, in such a way as to understand the similarities and the differences between the authors' backgrounds. Concerning the thematic, both narratives represent the diasporal process as experienced by the migrant child and the integration to the country of refuge. As a result, we observed that the socioeconomic conditions and the cultural formation of both families were decisive to the authors' integration to Brazilian culture.
\end{abstract}

Keywords: Migrant children. Migration. Exile. 


\section{REFERÊNCIAS}

ARENDT, H. Origens do totalitarismo. Tradução Roberto Raposo. São Paulo: Companhia das Letras, 1989.

ARIĖS, P. História social da criança e da família. Tradução Dora Flaksman. Rio de Janeiro: LTC, 1981.

BELINKY, T. Transplante de menina: da Rua dos Navios à Rua Jaguaribe. 3. ed. São Paulo: Moderna, 2003.

BLAY, E. A. O Brasil como destino: raízes da imigração judaica contemporânea para São Paulo. São Paulo: Editora Unesp, 2013.

CARR, E. H. A revolução bolchevique (1917-1923). Porto: Afrontamento, 1977. (História da Rússia Soviética, v. 1).

GOMES, L. O. As crianças e a migração: notas a respeito dos processos de socialização. In: MAZZA, D.; SIMSON, O. (org.). Mobilidade humana e diversidade sociocultural. Jundiaí: Paco Editorial, 2011.

HALBWACHS, M. A memória coletiva. Tradução Beatriz Sidou. São Paulo: Centauro, 2003.

HELD, J. O imaginário no poder: as crianças e a literatura fantástica. 2. ed. São Paulo: Summus, 1980. (Novas buscas em Educação, v. 7).

HEYWOOD, C. Uma história da infância: da Idade Média à época contemporânea no Ocidente. Tradução Roberto Cataldo Costa. Porto Alegre: Artmed, 2004. LISPECTOR, E. No exílio. 2. ed. Brasília: Ebrasa, 1971.

POLLAK, M. Memória, esquecimento, silêncio. Estudos históricos, Rio de Janeiro, v. 2, n. 3, p. 3-15, 1989.

ROLLEMBERG, D. Exílio: entre raízes e radares. Rio de Janeiro; São Paulo: Editora Record, 1999.

STEVENSON, D. 1914-1918: a história da Primeira Guerra Mundial. São Paulo: Novo Século, 2016.

WALDMAN, B. Clarice e Elisa Lispector: caminhos divergentes. Webmosaica, revista do instituto cultural judaico Marc Chagall, v. 6, n. 1, p. 10-17, jan./jun. 2014. 